\title{
EVALUASI BERBASIS KRITERIA UNTUK KESUKSESAN IMPLEMENTASI SISTEM INFORMASI KESEHATAN BERDASARKAN DELONE AND MCLEAN MODEL
}

\author{
Admaja Dwi Herlambang1, Satrio Hadi Wijoyo², Aditya Rachmadi ${ }^{3}$, Cindy Felita Nur Alimah ${ }^{4}$
}

1,2,3,4 Jurusan Sistem Informasi, Fakultas Ilmu Komputer, Universitas Brawijaya

Email: ${ }^{1}$ herlambang@ub.ac.id, ${ }^{2}$ satriohadi@ub.ac.id, ${ }^{3}$ rachmadi.aditya@ub.ac.id, ${ }^{4}$ cindyfelita@student.ub.ac.id

(Naskah masuk: 01 Desember 2018, diterima untuk diterbitkan: 13 Februari 2019)

\begin{abstract}
Abstrak
Penelitian bertujuan untuk mengevaluasi kesuksesan implementasi sistem informasi kesehatan (Homedika.com). Pengukuran dilakukan berdasarkan DeLone \& McLean Model. Pengumpulan data dilakukan melalui kuesioner yang telah lolos uji validitas dan reliabilitas. Sampel penelitian berjumlah 30 responden yang dipilih dengan menggunakan teknik purposive sampling dan data dianalisis dengan statistik jenis deskriptif. Hasil analisis kesuksesan pada variabel system quality, information quality, service quality, user satisfaction, dan net benefits masuk ke dalam kategori Tinggi, dan variabel use masuk ke dalam kategori Cukup Tinggi. Kesuksesan implementasi sistem informasi kesehatan dapat ditingkatkan dengan cara melakukan perbaika pada variabel use dengan indikator frequency of use.
\end{abstract}

Kata kunci: sistem informasi kesehatan, kesuksesan sistem informasi, DeLone and McLean Model

\section{CRITERIA-BASED EVALUATION FOR HEALTH INFORMATION SYSTEM IMPLEMENTATION SUCCESS BASED ON DELONE AND MCLEAN MODEL}

\begin{abstract}
The study aims to evaluate the success of health information systems (Homedika.com) implementation. Measurements are carried out based on DeLone \& McLean Model. Data collection was done through questionnaire that had passed the validity and reliability test. The research sample consisted of 30 respondents who were selected using purposive sampling technique and ata were analyzed using descriptive statistics formula. The results of success analysis in the system quality, information quality, service quality, user satisfaction, and net benefits variable categorized as High, and use variable categorized as Quite High. The success of the implementation of health information systems can be improved by improving the use variable with frequency of use indicator.
\end{abstract}

Keywords: health information system, information system success, DeLone and McLean Model

\section{PENDAHULUAN}

Indonesia Medika didirikan pada tahun 2010 oleh dr. Gamal Albinsaid Indonesia Medika yang berlokasi di Jalan Kedawung nomor 17 Malang. Salah satu program yang dimiliki oleh Indonesia Medika, yaitu Homedika. Homedika merupakan wirausaha sosial berbasis teknologi yang menghubungkan tenaga kesehatan dan fasilitas kesehatan dengan masyarakat untuk memberikan berbagai layanan kesehatan (homedika.com, 2016). Hadirnya Homedika akan membantu pasien mendapatkan layanan kesehatan di rumah mulai dari dokter, perawat, bidan, ahli gizi, psikolog, dan fisioterapi. Pasien yang ingin menggunakan layanan kesehatan Homedika dapat mengakses melalui alamat Homedika.com.
Wawancara yang telah dilakukan dengan koordinator web developer Indonesia Medika pada tanggal 14 Februari 2018 terdapat beberapa permasalahan terkait Homedika. Homedika memiliki beberapa tujuan, salah satunya yaitu mengimplementasikan Homedika di berbagai penjuru Indonesia. Namun, kondisi yang terjadi saat ini adalah masih minimnya tenaga kesehatan atau layanan kesehatan yang bergabung sehingga implementasi Homedika masih fokus di kota Malang. Permasalahan terkait website Homedika adalah beberapa pengguna merasa bahwa desain tampilan website kurang user friendly. Pada layanan Homedika masih belum ada fitur pencarian tenaga kesehatan atau layanan kesehatan berdasarkan lokasi pasien yang terkadang mengakibatkan adanya jarak yang 
cukup jauh antara lokasi rumah pasien dengan tenaga kesehatan.

Menjadi organisasi yang bergerak di bidang kesehatan dengan memanfaatkan teknologi perlu mengimplementasikan sistem informasi yang berkualitas dan sukses. Oleh karena itu, dapat diambil rumusan masalah berdasarkan uraian latar belakang permasalahan sebagai berikut: Bagaimana kualitas layanan Homedika berdasarkan variabel pada UTAUT Model, bagaimana kesuksesan implementasi layanan Homedika berdasarkan variabel pada model DeLone \& McLean, dan bagaimana rekomendasi yang diberikan untuk meningkatkan kualitas dan kesuksesan implementasi pada layanan Homedika.

Kriteria evaluasi yang digunakan pada penelitian ini adalah DeLone \& McLean Model merupakan model untuk mengukur kesuksesan implementasi sistem informasi berdasarkan enam pengukuran, yaitu system quality, information quality, service quality, use, user satisfaction, dan net benefit. System quality merupakan keseluruhan kinerja suatu sistem yang dirasakan oleh pengguna (Yu \& Qian, 2018). Information quality merupakan keluaran dari sistem informasi berupa informasi yang akan digunakan pengguna (Setyo \& Rahmawati, 2015) Service quality merupakan tingkat perbedaan antara harapan normatif pengguna dan persepsi dari organisasi dan personil teknologi informasi (TI) (DeLone \& McLean, 2003). Use merupakan tingkat seberapa sering pengguna memanfaatkan kemampuan sistem informasi (DeLone \& McLean, 2003). User satisfaction merupakan tingkat kepuasan pengguna setelah menggunakan sistem informasi (DeLone \& McLean, 2003). Net benefits merupakan sejauh mana sistem informasi membantu keberhasilan individu, kelompok atau organisasi (DeLone \& McLean, 2003).

\section{METODOLOGI}

Pendekatan evaluasi yang digunakan adalah evaluasi berbasis kriteria (criteria-based evaluation). Criteria-based evaluation merupakan kegiatan evaluasi yang bertujuan untuk mengungkap apakah kemampuan atau keadaan sistem informasi sesuai (comply) dengan kriteria yang telah ditetapkan oleh evaluator (Cronholm \& Goldkuhl, 2003). Kriteria yang digunakan adalah DeLone \& McLean Model untuk mengukur kesuksesan sistem informasi.

Pada Gambar 1 menggambarkan langkahlangkah yang telah dilakukan peneliti. Penelitian menggunakan pendekatan kuantitatif. Sumber data penelitian diperoleh dengan wawancara ke pihak Homedika dan penyebaran kuesioner ke pengguna Homedika.

Tahap pertama dengan merumuskan masalah berdasarkan wawancara dengan pihak Homedika. Selanjutnya, melakukan studi literatur mengenai teori kualitas dan kesuksesan berdasarkan jurnal, buku, dan penelitian sebelumnya. Kemudian, peneliti menentukan model yang digunakan, yaitu model DeLone \& McLean Model.

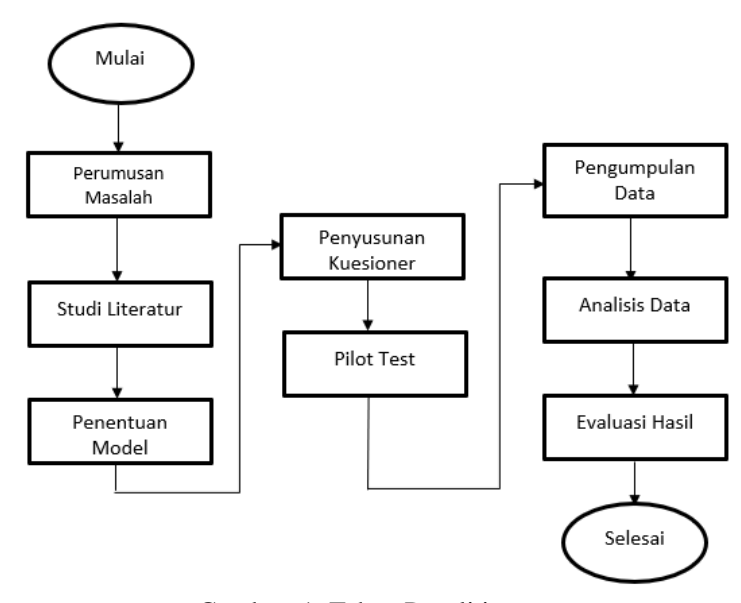

Gambar 1. Tahap Penelitian

Tahap selanjutnya yaitu penyusunan kuesioner dengan menetapkan indikator-indikator setiap variabel DeLone \& McLean Model berdasarkan penelitian terdahulu dan objek penelitian. Penelitian menggunakan skala likert 5 poin, yaitu: 1) sangat tidak setuju; 2) tidak setuju; 3) ragu-ragu; 4) setuju; 5) sangat setuju. Setelah penyusunan kuesioner maka melakukan pengujian melalui penilaian ahli (expert judgement) yang dilakukan oleh dua dosen ahli. Hasil dari penilaian ahli akan dihitung menggunakan formula Aiken's V. Pilot test dilakukan dengan menyebarkan kuesioner kepada 30 responden yang akan menghasilkan nilai validitas tiap butir pernyataan dan nilai reliabilitas. Pernyataan yang digunakan memiliki skor validitas lebih dari 0,361 dan hasil yang diperoleh keseluruhan variabel memiliki nilai Cronbach's Alpha lebih dari 0,60 sehingga kuesioner dapat dikategorikan reliabel.

Tabel 1. Kategori Nilai

\begin{tabular}{cc}
\hline Rentang Nilai & Kategori \\
\hline $83,35<x \leq 100$ & Sangat tinggi \\
$66,68<x \leq 83,35$ & Tinggi \\
$50,01<x \leq 66,68$ & Cukup tinggi \\
$33,34<x \leq 50,01$ & Cukup rendah \\
$16,67<x \leq 33,34$ & Rendah \\
$0<x \leq 16,67$ & Sangat rendah \\
\hline
\end{tabular}

Pada penelitian ini jumlah populasi adalah 132 pengguna yang pernah menggunakan pemesanan tenaga kesehatan Homedika di kota Malang. Teknik pengambilan sampel melalui sampling purposive dengan kriteria: 1) pengguna yang dimaksud merupakan pasien; 2) pengguna melakukan pemesanan melalui website Homedika; 3) pengguna berdomisili di Malang. Sampel yang digunakan pada penelitian berjumlah 30 orang. Pengumpulan data melalui kuesioner yang dilakukan dengan mendatangi langsung ke rumah pengguna Homedika di Kota Malang.

Data diolah dengan statistik deskriptif yang berfungsi untuk mendiskripsikan atau memberi 
gambaran terhadap obyek yang diteliti melalui data sampel atau populasi sebagaimana adanya, tanpa melakukan analisis dan membuat kesimpulan yang berlaku untuk umum (Sugiyono, 2017). Hasil nilai mean setelah diubah menjadi persentase akan digolongkan ke enam kategori menurut Azwar (2012) yang disajikan pada Tabel 1. Tahap terakhir pada penelitian ini yaitu menarik kesimpulan untuk menjawab rumusan masalah dan saran berdasarkan evaluasi pada penelitian yang telah dilakukan sehingga menjadi dasar untuk penelitian selanjutnya.

\section{HASIL}

Pada variabel system quality terdapat 4 indikator, yaitu system flexibility, system reliability, security, dan response times. Hasil analisis data system quality disajikan pada Tabel 2. Nilai system quality secara keseluruhan termasuk dalam kategori tinggi dengan persentase sebesar $71,70 \%$. Indikator response times dan system reliability memiliki rata-rata sehingga keduanya direkomendasikan untuk dilakukan perbaikan.

Tabel 2. Analisis System Quality

\begin{tabular}{lcccc}
\hline \multirow{2}{*}{ Indikator } & \multicolumn{2}{c}{ Mean } & \multirow{2}{*}{ St. Dev. } & Variance \\
\cline { 2 - 3 } & Skor & $\boldsymbol{\%}$ & & \\
\hline $\begin{array}{l}\text { System } \\
\text { flexibility }\end{array}$ & 3,77 & 75,40 & 0,82 & 0,67 \\
$\begin{array}{l}\text { System } \\
\text { reliability }\end{array}$ & 3,47 & 69,40 & 0,97 & 0,95 \\
$\begin{array}{l}\text { Security } \\
\text { Response times }\end{array}$ & 3,63 & 72,60 & 0,77 & 0,59 \\
\hline \multicolumn{1}{r}{ Total } & & 69,40 & 0,97 & 0,95 \\
\hline \multicolumn{1}{r}{} & 71,70 & Kategori & Tinggi \\
\hline
\end{tabular}

Pada variabel information quality terdapat 3 indikator, yaitu information completeness, format, relevance, accurate, dan timeliness. Hasil analisis data information quality disajikan pada Tabel 7. Nilai information quality secara keseluruhan termasuk dalam kategori tinggi dengan persentase sebesar $73,72 \%$. Indikator timeliness memiliki rata-rata di bawah rata-rata total sehingga menjadi prioritas pertama yang direkomendasikan untuk dilakukan perbaikan

Tabel 3. Analisis Information Quality

\begin{tabular}{lcccc}
\multicolumn{5}{c}{ Tabel 3. Analisis Information Quality } \\
\cline { 2 - 3 } \multicolumn{1}{c}{ Indikator } & \multicolumn{2}{c}{ Mean } & \multirow{2}{*}{ St. Dev. } & \multirow{2}{*}{ Variance } \\
\cline { 2 - 3 } Information & 3,80 & 76,00 & 0,85 & 0,72 \\
completeness & 3,73 & 74,60 & 0,87 & 0,75 \\
Format & 3,90 & 78,00 & 0,71 & 0,51 \\
Relevance & 3,87 & 77,40 & 0,73 & 0,53 \\
Accurate & 3,13 & 62,60 & 1,07 & 1,15 \\
Timeliness & & 73,72 & Kategori & Tinggi \\
\hline \multicolumn{1}{c}{ Total } & & & & \\
\hline
\end{tabular}

Tabel 4. Analisis Service Quality

\begin{tabular}{lcccc}
\hline \multirow{2}{*}{ Indikator } & \multicolumn{2}{c}{ Mean } & \multirow{2}{*}{ St. Dev. } & \multirow{2}{*}{ Variance } \\
\cline { 2 - 3 } & Skor & $\boldsymbol{\%}$ & & \\
\hline $\begin{array}{l}\text { Information } \\
\text { completeness }\end{array}$ & 3,80 & 76,00 & 0,81 & 0,65 \\
Format & 3,83 & 76,60 & 0,75 & 0,56 \\
\hline \multicolumn{1}{r}{ Total } & & 78,30 & Kategori & Tinggi \\
\hline
\end{tabular}

Pada variabel service quality terdapat 2 indikator, yaitu assurance dan empathy. Hasil analisis data service quality disajikan pada Tabel 4. Nilai service quality secara keseluruhan termasuk dalam kategori tinggi dengan persentase sebesar 76,30\%. Indikator assurance memiliki rata-rata di bawah ratarata total sehingga menjadi prioritas pertama yang direkomendasikan untuk dilakukan perbaikan.

\begin{tabular}{|c|c|c|c|c|}
\hline \multirow{2}{*}{ Indikator } & \multicolumn{2}{|c|}{ Mean } & \multirow{2}{*}{ St. Dev. } & \multirow{2}{*}{ Variance } \\
\hline & Skor & $\%$ & & \\
\hline Frequency of & 3,03 & 60,60 & 1,10 & 1,21 \\
\hline use & 3,37 & 67,40 & 0,96 & 0,93 \\
\hline Total & & 63,70 & Kategori & Cukup Tinggi \\
\hline
\end{tabular}

\begin{tabular}{|c|c|c|c|c|}
\hline \multirow{2}{*}{ Indikator } & \multicolumn{2}{|c|}{ Mean } & \multirow{2}{*}{ St. Dev. } & \multirow{2}{*}{ Variance } \\
\hline & Skor & $\%$ & & \\
\hline Repeat visits & 3,00 & 60,00 & 0,95 & 0,90 \\
\hline Repeat purchase & 3,67 & 73,40 & 0,76 & 0,58 \\
\hline Total & & 66,70 & Kategori & Tinggi \\
\hline
\end{tabular}

Pada variabel use memiliki 1 indikator yaitu frequency of use. Hasil analisis data use disajikan pada Tabel 9. Nilai use secara keseluruhan termasuk dalam kategori cukup tinggi dengan persentase sebesar $63,7 \%$. Dari hasil analisis tersebut ditemukan sub-indikator yang memiliki rata-rata di bawah ratarata total yaitu sub-indikator pertama.

Pada variabel user satisfaction terdapat dua indikator, yaitu repeat visits dan repeat purchase. Hasil analisis data user satisfaction disajikan pada Tabel 6. Nilai user satisfaction secara keseluruhan termasuk dalam kategori tinggi dengan persentase sebesar 66,70\%. Dari hasil analisis tersebut ditemukan indikator repeat visits memiliki rata-rata di bawah rata-rata total sehingga menjadi prioritas pertama yang direkomendasikan untuk dilakukan perbaikan.

Pada variabel net benefits terdapat 2 indikator, yaitu effectiveness dan improved knowledge sharing. Hasil analisis data net benefits disajikan pada Tabel 7. Nilai net benefits secara keseluruhan termasuk dalam kategori tinggi dengan persentase sebesar 73,70\%. Dari hasil analisis tersebut ditemukan indikator effectiveness memiliki rata-rata di bawah rata-rata total sehingga menjadi prioritas pertama yang direkomendasikan untuk dilakukan perbaikan.

\begin{tabular}{lcccc}
\multicolumn{5}{c}{ Tabel 7. Analisis Net Benefits } \\
\hline \multirow{2}{*}{ Indikator } & \multicolumn{2}{c}{ Mean } & \multirow{2}{*}{ St. Dev. } & Variance \\
\cline { 2 - 3 } & Skor & $\mathbf{\%}$ & & \\
\hline $\begin{array}{l}\text { Effectiveness } \\
\text { Improved } \\
\text { knowledge sharing }\end{array}$ & 3,57 & 71,40 & 0,77 & 0,60 \\
\hline \multicolumn{1}{c}{ Total } & & 76,00 & 0,66 & 0,44 \\
\hline
\end{tabular}

\section{PEMBAHASAN}

Variabel system quality dalam penelitian ini untuk mengetahui kualitas dari hardware dan software layanan website Homedika. Variabel system quality memiliki empat indikator yaitu fleksibilitas 
sistem (system flexibility), keandalan sistem (system reliability), keamanan sistem (security), dan kecepatan akses (response times). Indikator system reliability dan response times menjadi prioritas pertama untuk dilakukan perbaikan. Saat performa website Homedika diuji menggunakan GTMetrix menunjukkan bahwa website Homedika masuk dalam kategori rendah. Hal yang perlu diperhatikan pada layanan website Homedika untuk meningkatkan kualitas sistem agar lebih optimal bisa dengan mengurangi ukuran file gambar atau video yang ditampilkan pada website Homedika. Menurut Mohamadali \& Aziz (2017) juga berpendapat bahwa sebuah sistem harus bebas dari kesalahan dan dapat menjalankan fungsinya dalam waktu yang singkat. Kesuksesan sistem dapat ditunjukkan dari Interaksi sistem dengan penggunanya. Pengguna akan merasa puas saat sistem yang digunakan memiliki kestabilan yang baik sehingga membantu dalam melakukan aktivitas. Stabil memiliki arti bahwa saat pengguna mengakses suatu menu maka tidak ada gangguan seperti adanya larangan akses informasi di dalamnya.

Variabel information quality dalam penelitian ini untuk mengetahui kualitas informasi yang ada pada layanan website Homedika. Variabel information quality memiliki lima indikator yaitu kelengkapan informasi (information completeness), penyajian informasi (format), relevansi (relevance), akurat (accurate), dan ketepatan waktu (timeliness). Indikator timeliness menjadi prioritas pertama untuk dilakukan perbaikan. Tenaga kesehatan dan layanan kesehatan sangat penting bagi pasien namun pada kenyatannya masih banyak tenaga medis yang belum tersedia namun tertera pada pilihan sehingga pasien tidak dapat melakukan pemesanan layanan. Pada tenaga kesehatan atau layanan kesehatan yang telah tersedia, informasi yang tertera juga belum lengkap seperti tidak adanya nama dan foto dokter. Information quality memiliki pengaruh yang kuat terhadap kepuasan pengguna (Delone \& McLean, 1992). Information quality dapat diartikan dengan pengukuran kualitas konten dari sistem informasi. Sistem informasi yang mampu menghasilkan informasi dengan tepat waktu, akurat, dan relevan serta memenuhi kriteria dan ukuran lain tentang kualitas informasi akan berdampak terhadap kepuasan pengguna. (Fendini, Kertahadi \& Riyadi, 2016, 2016). Rekomendasi perbaikan yang diberikan adalah memperbaharui informasi yang penting pada layanan website Homedika.

Variabel service quality dalam penelitian ini untuk mengetahui harapan pengguna dengan kinerja yang diberikan oleh layanan website Homedika. Variabel service quality memiliki dua indikator yaitu assurance dan empathy. Indikator assurance menjadi prioritas pertama untuk dilakukan perbaikan. Homedika memiliki layanan customer chat pada website bagi pengguna yang membutuhkan bantuan namun customer chat yang dimiliki Homedika seringkali offline. Hal yang perlu ditingkatkan pada layanan website Homedika adalah meningkatkan kualitas customer chat pada admin atau customer service Homedika sehingga pengguna benar-benar merasa terpenuhi kebutuhannya. Adanya fitur notifikasi pada website juga penting bagi pengguna sehingga lebih mudah dalam mendapatkan notifikasi. Elmorshidy, Mostafa, El-Moughrabi, dan Al-Mezen (2015) juga berpendapat bahwa era yang ada saat ini di mana pengguna lebih banyak meminta pertanyaan dan masalah yang harus diselesaikan secara cepat, daripada menunggu untuk menerima balasan

Variabel use dalam penelitian ini untuk mengetahui tingkat penggunaan pengguna terhadap layanan website Homedika Variabel use memiliki satu indikator yaitu frekuensi penggunaan (frequency of use). Hasil analisis statistik deskriptif use menunjukkan pada kategori cukup tinggi. Pengguna percaya keputusan untuk menggunakan sistem bergantung pada persepsi harapan kinerja dan kualitas desain website (Al-Qeisi, Dennis, Alamanos, \& Jayawardhena, 2014). Peningkatan dari segi performance expectancy dan effort expectancy akan memengaruhi pengguna untuk pertama kali mengunjungi website Homedika. Setelah pengguna merasa tertarik maka akan meningkatkan niat pengguna untuk terlibat dalam website tersebut.

Variabel user satisfaction dalam penelitian ini untuk mengetahui tingkat kepuasan penngguna layanan website Homedika. Variabel user satisfaction memiliki dua indikator repeat visits dan repeat purchase. Sementara indikator repeat visits menjadi prioritas pertama untuk dilakukan perbaikan. Penelitian yang dilakukan oleh Ghasemaghaei \& Hassanein (2015) menyatakan bahwa information quality memengaruhi secara kuat kepuasan pengguna. Pengaruh tersebut sangat penting terutama pada situs e-services. Pengembang situs web $e$ services harus lebih fokus pada dimensi yang ada pada information quality seperti akurasi, kelengkapan, dan keandalan informasi untuk meningkatkan kepuasan pengguna (Ghasemaghaei \& Hassanein, 2015). Hal yang yang perlu diperhatikan oleh Homedika terkait kepuasan pengguna adalah meningkatkan akurasi, kelengkapan, dan keandalan informasi pada website. Sehingga pengguna tidak hanya melakukan kunjungan berulang namun melakukan pemesanan layanan berulang.

DeLone \& McLean (2016) mendefinisikan net benefits sebagai sejauh mana sistem informasi membantu keberhasilan individu, kelompok, organisasi, indutri, dan Negara. Selain itu, net benefits juga untuk mengetahui ukuran keseluruhan hasil akhir dari penggunaan sistem informasi termasuk dari sisi pengguna dan organisasi. Variabel net benefits memiliki dua indikator efektivitas (effectiveness) dan meningkatkan pengetahuan (improved knowledge sharing). Indikator effectiveness menjadi prioritas pertama untuk dilakukan perbaikan. Homedika memilki beberapa tujuan untuk pasien yang menggunakan Homedika antara lain, dapat 
menghemat waktu melalui layanan segera, dapat memilih tenaga kesehatan sesuai keinginan, dan lainlain. Menurut hasil analisis statistik deskriptif terkait effectiveness yang membutuhkan peningkatan bisa terjadi karena pengguna belum terlalu merasakan keuntungan dari penggunaan Homedika. Jika effectiveness pada Homedika tinggi maka dapat diartikan bahwa net benefits akan terpenuhi. Dengan banyaknya aplikasi m-Health, penyedia harus mampu mengembangkan keterampilan untuk menemukan kebutuhan pengguna sehingga dapat mengimplementasikan aplikasi yang memiliki efektivitas. Hal yang perlu diperhatikan pada layanan website Homedika adalah mempertahankan kualitas website dengan memuat isi website yang sesuai dengan kebutuhan pengguna dan memberikan informasi yang lebih lengkap. Selain itu, melakukan evaluasi apakah tujuan yang dimiliki Homedika sudah tercapai atau belum. Beberapa hal yang penting bagi penyedia yaitu (1) aplikasi m-Health memberikan informasi yang lebih lengkap (2) aplikasi m-Health mempromosikan keterlibatan pasien dalam tindakan yang nyata (3) aplikasi $m$ Health bisa menambahkan fitur terkait pemantauan perawatan pengguna (Niles, 2016).

\section{SIMPULAN}

Hasil statistik deskriptif pada model DeLone \& McLean Model menunjukkan bahwa kondisi variabel yang masuk kategori Tinggi, yaitu system quality, information quality, service quality, user satisfaction dan net benefits; dan use termasuk kategori Cukup Tinggi. Aspek yang perlu ditingkatkan adalah variabel use. Rekomendasi yang diberikan untuk meningkatkan kualitas dan kesuksesan implementasi pada layanan Homedika, yaitu memiliki tenaga kesehatan tetap dalam pelayanan, memperhatikan desain website Homedika, memperbaiki tampilan FAQ lebih sederhana, melakukan promosi online dengan pengunggahan konten secara intensif pada sosial media serta melakukan promosi offline, menambah fitur simulasi atau demo mengenai cara kerja pemesanan tenaga, memperbaharui informasi yang penting, adanya fitur notifikasi pada website, dan melakukan evaluasi atau riset pada website Homedika.

Penelitian selanjutnya bisa dengan melakukan penelitian terkait terkait redesign tampilan sistem informasi sehingga dapat meningkatkan tingkat penerimaan sistem informasi Homedika. Penelitian terkait goal-based evaluation juga dapat dilakukan guna mengetahui tujuan dari Homedika apakah sudah tercapai atau belum.

\section{DAFTAR PUSTAKA}

AL-QEISI, K., DENNIS, C., E. A. \& JAYAWARDHENA, C., 2014. Website Design Quality and Usage Behavior: Unified
Theory of Acceptance and Use of Technology. Journal of Business Research, pp. 2282-2290.

AZWAR, S., 2012. Reliabilitas dan Validitas. 4 penyunt. Yogyakarta: Pustaka Belajar.

CRONHOLM, S. \& GOLDKUHL, G., 2003. Strategies for Information System Evaluation: Six Generic Types. Electronic Journal of Information System Evaluation, 6(2), pp. 1-16.

DELONE, W. H. \& MCLEAN, E. R., 1992. Information System Success: The Quest for the Dependent Variable. The Institute of Management Sciences, pp. 60-92.

DELONE, W. \& MCLEAN, E., 2003. The DeLone and McLean Model of Information Systems Success; A Ten-Year Update. Journal Management Information Systems, 19(4), pp. 9-30.

ELMORSHIDY, A., MOSTAFA, M. M., ELMOUGHRABI, I. \& AL-MEZEN, H., 2015. Factors Influencing Live Customer Support Chat Services: An Empirical Investigation in Kuwait. Journal of Theoretical and Applied Electronic Commerce Research, 10(3), pp. 6376.

FENDINI, D. S., KERTAHADI \& RIYADI, 2016. Pengaruh Kualitas Sistem dan Kualitas Informasi terhadap Kepuasan Pengguna. pp. $1-11$.

GHASEMAGHAEI, M. \& HASSANEIN, K., 2015. Online Information Quality and Consumer Satisfaction: The Moderating Roles of Contextual Factors - A Meta-Analysis. Information \& Management, Volume 52, pp. 965-981.

HOMEDIKA.COM, 2016.2 [Online] Available at: http://landing.homedika.com/\# [Diakses 18 February 2018].

MAYMAND, M. M. \& GHAHREMANI, L., 2016. The Effect of Quality Dimensions of Web Design and UTAUT Model on the Behavior of Online Banking. International Journal of Humanities and Cultural Studies, Issue 2016, pp. 865-878.

MOHAMADALI, N. A. \& AZIZ, N. F. A., 2017. The Technology Factors as Barriers for Sustainable Health Information Systems (HIS) - A Review. Elsevier B.V, pp. 370-378.

MOORE, G. C. \& BENBASAT, I., 1991. Development of an Instrument to Measure the Perceptions of Adopting an Information Technology Innovation. Information Systems Research, pp. 192-222.

NILES, L. F., 2016. A Best Practice Guide for the Usage of Mobile Health Applications. Capstones, pp. 1-136.

ROGERS, E. M., 1983. Diffusion of Innovations. 3th penyunt. New York: The Free Press.

SETYO, D. \& RAHMAWATI, D. A., 2015. EFEKITIF Jurnal Bisnis dan Ekonom. Pengaruh Kualitas Informasi dan Kualitas 
320 Jurnal Teknologi Informasi dan Ilmu Komputer (JTIIK), Vol. 6, No. 3, Juni 2019, hlm. 315-320

Sistem Informasi terhadap Kepuasan Serta Kinerja Pengguna Sistem Informasi, Volume 6, pp. 47-59.

SNIJDERS, R. \& HELMS, R., 2014. Analyzing Social Influence Through Social Media, A Structured Literature Review. Proceedings of the 7th IADIS International Conference on Information Systems, pp. 1-8.

SUGIYONO, 2017. Statistika untuk Penelitian. 28 penyunt. Bandung: Alfabeta.

VEER, A. J. E. D. ET AL., 2015. Determinants of the Intention to Use e-Health by Community Dwelling Older People. BMC Health Services Research, pp. 1-9.

VENKATESH, V., MORRIS, M. G., DAVIS, G. B. \& DAVIS, F. D., 2003. User Acceptance of Information Technology : Toward a Unified View. MIS Quarterly, 27(3), pp. 425-478.

YEOW, P. H., YUEN, Y. Y. \& TONG, D. Y. K., 2008. User acceptance of Online Banking Service in Australia. Communications of the IBIMA, Volume 1, pp. 191-197.

YU, P. \& QIAN, S., 2018. Developing a Theoretical Model and Questionnaire Survey Instrument to Measure the Success of Electronic Health Records in Residential Aged Care. PLOS ONE, pp. 1-18. 